\title{
UJI AKTIVITAS ANTIMIKROBA DARI JAMUR LAUT YANG BERASOSIASI DENGAN ORGANISME LAUT SPONS Callyspongia aerizusa
}

\author{
Fransisca Macpal ${ }^{1)}$, Adithya Yudistira ${ }^{1)}$, Defny Wewengkang ${ }^{1)}$ \\ ${ }^{1)}$ Program Studi Farmasi FMIPA UNSRAT Manado, 95115
}

\begin{abstract}
Sponge is the lowest level hollow animal without a spine. Sponges are one of the components of coral reef biota that have bioactive potential that has not been widely used. This study aims to determine whether there is antimicrobial activity of marine fung $i$ associated with sponge Callyspongia aerizusa obtained from Southeast Minahasa Regency, North Sulawesi, against the growth of microbes such as Staphylococcus aureus, Escherichia coli and Candida albicans. Samples were obtained then extracted by maceration using acetone and fractionated using liquid-liquid fractionation with ethyl acetate solvents. The results of this study indicate that the extract from the fungus associated with the Callyspongia aerizusa sponge has activity against Escherichia coli and Candida albicans.
\end{abstract}

Keywords: Antimicrobials, Callyspongia aerizusa, Candida albicans, Escherichia coli, Marine fungi, Staphylococcus aureus.

\begin{abstract}
ABSTRAK
Sponge (spons laut) adalah hewan berongga tanpa tulang belakang yang paling rendah tingkatannya. Spons merupakan salah satu komponen biota penyusun terumbu karang yang mempunyai potensi bioaktif yang belum banyak dimanfaatkan. Penelitian ini bertujuan untuk mengetahui apakah terdapat aktivitas antimikroba dari jamur laut yang berasosiasi dengan spons Callyspongia aerizusa yang di peroleh dari Kabupaten Minahasa Tenggara, Sulawesi Utara, terhadap pertumbuhan mikroba seperti Staphylococcus aureus, Escherichia coli dan Candida albicans. Sampel diperoleh kemudian diekstraksi secara maserasi dengan aseton dan difraksinasi dengan menggunakan fraksinasi cair-cair menggunakan pelarut etil asetat. Hasil penelitian ini menunjukkan bahwa ekstrak dari jamur yang berasosiasi dengan spons Callyspongia aerizusa memiliki aktivitas terhadap bakteri Escherichia coli dan bakteri Candida albicans.
\end{abstract}

Kata kunci: Antimikroba, Callyspongia aerizusa, Candida albicans Escherichia coli,.Jamur laut, Staphylococcus aureus 


\section{PENDAHULUAN}

Perairan laut Indonesia kaya akan berbagai biota laut baik flora maupun fauna. Demikian luas serta keragaman jasad-jasad hidup yang kesemuanya membentuk dinamika kehidupan di laut yang berkesinambungan (Nybakken, 1988). Provinsi Sulawesi Utara merupakan salah satu provinsi di Indonesia yang memiliki kondisi alam yang unik dengan keanekaragaman hayati yang tinggi. Provinsi Sulawesi Utara merupakan wilayah yang potensial, strategis dan memiliki garis pantai yang panjang kurang lebih sekitar $1.985 \mathrm{~km}$ (Ruyitno, 2002).

Sponge (spons laut) adalah hewan berongga tanpa tulang belakang yang paling rendah tingkatannya. Dikatakan hewan tingkat rendah karena struktur tubuhnya hanyalah suatu benda seperti jelly (mesohyl) yang ditutup oleh 2 lapisan. Epidermisnya adalah Pinakosit dan Endodermisnya adalah Koanosit. Spons merupakan salah satu komponen biota penyusun terumbu karang yang mempunyai potensi bioaktif yang belum banyak dimanfaatkan. Hewan laut ini mengandung senyawa aktif yang persentase keaktifannya lebih besar dibandingkan dengan senyawa-senyawa yang dihasilkan oleh tumbuhan darat (Bugni,2004).

Potensi jamur yang berasal dari biota laut (marine-derived fungi) sebagai antibiotika sudah dikenal seja ditemukannya cephalosporin C, yang diisolasi dari jamur Acremonium chyrsogenum pada tahun 1946 di perairan Sardinia. Namun, penelitian terhadap marine-derived fungi baru berkembang sejak 10 tahun terakhir (Suciati et al., 2014).

\section{METODOLOGI PENELITIAN}

Waktu dan Tempat

Penelitian

Penelitian ini dilaksanakan pada bulan Mei 2019 sampai bulan September 2019 di Laboratorium Farmasi Lanjut Fakultas Matematika dan Ilmu Pengetahuan Alam Universitas Sam Ratulangi

\section{Alat dan Bahan}

Alat yang digunakan dalam penelitian ini yaitu masker, sarung tangan, gunting, scuba diving, kantong plastik, kamera bawah laut, wadah kaca, pisau, erlenmeyer (pyrex), corong, rotary evaporator, timbangan digital, gelas ukur (pyrex), gelas kimia (pyrex), cawan petri, corong pisah (pyrex), autoklaf, pinset, spatula, pembakar spritus, magnetic stirrer, pipet tetes, mikro tub, batang pengaduk, laminar air flow, rak tabung reaksi, tabung reaksi, lemari pendingin, inkubator, cakram (paper disc), mikropipet, vial, jangka sorong, jarum ose.

Bahan-bahan yang digunakan yaitu bakteri uji Staphylococcus aureus ATCC 25923, Escherichia coli ATCC 25922, jamur uji Candida albicans ATCC 1231, etanol, aquadest, etil asetat, aseton, Potato Dextro Agar, Nutrient Agar, Glukosa , Polypeptone, $\mathrm{MgSO}_{4} .7 \mathrm{H}_{2} \mathrm{O}$, Yeast Extract, $\mathrm{KH}_{2} \mathrm{PO}_{4}$, Sukrosa, Starch, Malt Extract, Ebios, larutan $\mathrm{H}_{2} \mathrm{SO}_{4} 1 \%$, larutan $\mathrm{NaCl} 0,9 \%$, kloramfenikol paperdisc, label, spidol permanen, tissue, aluminium foil, kertas saring, kapas. 


\section{Pengambilan Sampel dan Persiapan Sampel}

Sampel spons Callyspongia aerizusa diambil dari perairan desa Tumbak kecamatan Pusomaen Minahasa Tenggara Sulawesi Utara menggunakan alat bantu (Scuba Diving), diambil kemudian dimasukan ke dalam ziper bag dan disimpan dalam cooling box berisi es batu untuk dibawah ke Laboratorium Farmasi Lanjut Fakultas Matematika dan Ilmu Pengetahuan Alam Universitas Sam Ratulangi.

\section{Isolasi dan purifikasi jamur yang berasosiasi dengan spons}

Isolasi jamur dilakukan dengan cara sampel dibersihkan dengan aquades kemudian dipotong kecil-kecil menggunakan gunting dan pinset dan dimasukkan ke dalam media PDA yang telah disiapkan. Sampel ditanam di atas media PDA dengan tiga titik pusat yang berbentuk segitiga. Cawan petri yang berisi sampel ditutup dan direkatkan menggunakan parafilm, kemudian diinkubasi pada suhu ruangan selama $7 \times 24$ jam. Setelah didapatkan isolat jamur, dilakukan pemurnian dengan cara isolat jamur diinokulasikan ke media PDA yang baru, kemudian diinkubasi pada suhu ruangan selama 14x24 jam. Selanjutnya diidentifikasi morfologi secara makroskopik untuk menghasilkan isolat jamur murni.

\section{Ekstraksi}

Ekstraksi dilakukan pada campuran miselium jamur dan broth dengan menggunakan $200 \mathrm{~mL}$ aseton. Ekstraksi dilakukan dengan menggunakan shaker pada suhu ruangan dengan kecepatan $150 \mathrm{rpm}$ selama 5 menit. Selanjutnya dipisahkan antara fase air dan aseton menggunakan corong pisah dan kertas saring. Setelah didaptkan filtrat dari hasil penyaringan kemudian diuapkan dengan rotary evaporator.

\section{Fraksinasi}

Ekstrak cair dari hasil evaporasi, dimasukkan ke dalam corong pisah dan ditambahkan pelarut etil asetat sebanyak $200 \mathrm{~mL}$ setelah itu dikocok dalam corong pisah sampai homogen. Dibiarkan sampai terbentuk dua lapisan. Masing-masing lapisan ditampung pada wadah yang berbeda. Lapisan $\mathrm{H}_{2} \mathrm{O}$ (air) kemudian difraksinasi lagi menggunakan pelarut etil asetat sebanyak $200 \mathrm{~mL}$. Hal ini dilakukan sebanyak tiga kali. Selanjutnya fraksi etil asetat dikumpulkan kemudian pelarut diuapkan menggunakan rotary evaporator sampai diperoleh ekstrak kasar yang akan digunakan untuk uji aktivitas antimikroba.

\section{Sterilisasi Alat}

Alat-alat yang akan digunakan dalam penelitian uji aktivitas antimikroba harus disterilkan terlebih dahulu. Alatalat gelas disterilkan menggunakan autoklaf pada suhu $121^{\circ} \mathrm{C}$ selama \pm 15 menit pinset, gunting, dan jarum ose direndam dengan alkhohol dan dibakar dengan pembakaran di api langsung dan media disterilkan menggunakan autoklaf pada suhu $121^{\circ} \mathrm{C}$ selama 15 menit.

\section{Pembuatan Media}

\section{Media Potato Dextros Agar (PDA)}

Sebanyak 4,2 gram Potato Dextros Agar (PDA) ditambahkan air laut 
sampai $100 \mathrm{~mL}$ diaduk sampai homogen. Media tersebut disterilkan di dalam autoklaf pada suhu $121^{\circ} \mathrm{C}$ selama 15 menit, kemudian dipindahkan pada cawan petri dan didinginkan. Media tersebut digunakan sebagai media isolasi jamur.

\section{Media Nutrien Agar (NA)}

Sebanyak 3,36 gram Nutrien Agar ditambahkan aquades sampai $120 \mathrm{~mL}$ diaduk sampai homogen. Media tersebut disterilkan di dalam autoklaf pada suhu $121^{\circ} \mathrm{C}$ selama 15 menit, kemudian dipindahkan pada cawan petri dan didinginkan (Nuraina, 2015).

\section{Media Agar Miring}

Nutrien agar (NA) sebanyak 0,784 gram dilarutkan dalam $28 \mathrm{ml}$ aquades dan Potato Dextros Agar (PDA) sebanyak 0,588 gram dilarutkan dalam $14 \mathrm{~mL}$ aquades menggunakan erlenmeyer dan diaduk sampai homogen. Media tersebut disterilkan di dalam autoklaf pada suhu $121^{\circ} \mathrm{C}$ selama 15 menit, kemudian dibiarkan pada suhu ruangan sampai media memadat pada kemiringan 300. Media agar miring digunakan untuk inokulasi mikroba (Lay, 1994).

\section{Media Kultur Cair}

1. Sebanyak 2 gram glukosa, 0,5 gram polypeptone, $0,05 \quad$ gram $\mathrm{MgSO}_{4} \cdot 7 \mathrm{H}_{2} \mathrm{O}, \quad 0,2$ gram yeast extract, 0,1 gram $\mathrm{KH}_{2} \mathrm{PO}_{4}, \quad 0,1$ gram agar dilarutkan dalam $100 \mathrm{~mL}$ aquades menggunakan erlenmeyer dan diaduk sampai homogen dan disterilkan. Kemudian isolat jamur murni diinokulasikan ke dalam media pembenihan dan dishaker di dalam inkubator shaker selama $3 \times 24$ jam (Yamazaki et al., 2012).

2. Sebanyak 4,5 gram sukrosa, 4,5 gram starch, 1,5 gram extract malt, 0,45 gram ebios, 0,75 $\mathrm{KH}_{2} \mathrm{PO}_{4}$, 0,075 gram $\mathrm{MgSO}_{4}$ dilarutkan dalam $150 \quad \mathrm{~mL}$ aquades menggunakan erlenmeyer dan diaduk sampai homogen dan disterilkan. Kemudian diinokulasikan bibit kultur dari media pembenihan dan dishaker di dalam inkubator shaker selama 7x24 jam (Yamazaki et al., 2012).

\section{Pembuatan Suspensi Mikroba Uji}

Mikroba yang telah diinokulasi diambil dengan jarum ose steril kemudian disuspensikan ke dalam tabung reaksi yang berisi $7 \mathrm{~mL}$ larutan $\mathrm{NaCl} 0.9 \%$, setelah itu divortex hingga diperoleh kekeruhan yang sama dengan larutan $M c$. Farland Perlakuan yang sama dilakukan pada jamur uji (Dwyana et al., 2012).

\section{Pembuatan Kontrol Positif dan Kontrol Negatif}

Kontrol positif yang digunakan yaitu antibiotik kloramfenikol. Kontrol negatif yang digunakan dalam penelitian ini yaitu menggunakan metanol, dengan cara membuat larutan stok metanol dengan mengambil sebanyak $200 \mu \mathrm{l}$ metanol kemudian ditotolkan pada paper disc.

\section{Pembuatan Larutan Uji}

Dibuat larutan uji dengan cara ditimbang ekstrak kasar jamur dari spons Callyspongia aerizusa. sebanyak $1 \mathrm{mg}$, kemudian dilarutkan dalam 200ml metanol sehingga menghasilkan 
konsentrasi larutan uji sebesar $250 \mu \mathrm{g} / 50$ $\mu l$ (Ortez, 2005).

\section{Pengujian Aktivitas Antimikroba}

Metode yang digunakan dalam penelitian ini yaitu metode kertas cakram (cara Kirby and Bauer). Aktivitas penghambatannya diuji terhadap Staphylococcus aureus ATCC 25923 (bakteri Gram positif), Eschrichia coli ATCC 25922 (bakteri Gram negatif) dan Candida albicans ATCC 1231 (jamur), yang digunakan sebagai mikroorganisme uji. Pada pengujian aktivitas antimikroba ini, cakram (paper disc) yang digunakan berukuran $6 \mathrm{~mm}$. Suspensi mikroba kemudian diinokulasikan ke dalam media dan dihomogenkan. Kemudian media yang telah diinokulasi mikroba dituangkan ke dalam cawan petri dan tunggu sampai media memadat. Masingmasing cawan petri diberi label dan nomor sampel yang sesuai.

Sampel yang telah ditentukkan konsentrasinya $(250 \mu \mathrm{g} / 50 \mu \mathrm{L})$ ditotolkan pada masing-masing cakram dengan menggunakan mikropipet. Letakkan kertas cakram yang telah ditotolkan sampel uji dengan pinset kedalam cawan petri lalu diinkubasi selama 1 x 24 jam (Ortez, 2005).

\section{Pengamatan dan Pengukuran Zona Bening}

Pengamatan dilakukan setelah 1x24 jam masa inkubasi. Zona bening merupakan petunjuk kepekaan mikroba terhadap bahan antimikroba yang digunakan sebagai bahan uji yang dinyatakan dengan lebar diameter zona hambat. Diameter zona hambat diukur kemudian dikategorikan kekuatan daya antimikrobanya

berdasarkan penggolongan (Vandepite, 2005).

\section{HASIL DAN PEMBAHASAN}

\section{Isolasi dan Purifikasi Jamur yang Berasosiasi dengan Spons}

Koloni jamur yang yang tumbuh diamati perbedaan karakteristik secara mikroskopik. Dalam penelitian ini setelah $3 \times 24$ jam, isolat jamur yang tumbuh terlihat seperti benang-benang halus yang berwarna putih. Selanjutnya isolat jamur yang tumbuh dilakukan dengan cara diinokulasikan ke media PDA yang baru dan diinokulasikan selama $14 \times 24$ jam pada suhu ruangan. Hal ini bertujuan untuk dapat memisahkan koloni-koloni jamur agar dapat menghasilkan isolat jamur yang karakteristik secara mikroskopik yang mempunyai morfologi yang sama agar dapat disebut isolat jamur murni.

\section{Kultur Cair}

Dalam penelitian ini isolat jamur dikultivasi sebanyak dua kali dengan periode yang berbeda. Kultivasi yang pertama dilakukan selama 3x24 jam untuk menghasilakn bibit kultur. Kultivasi yang kedua dilakukan selama 14x24 jam untuk menghasilkan senyawa dari bibit kultur. Kultivasi dilakukan dengan menggunakan metode shaker pada suhu $27^{\circ} \mathrm{C}$ dengan kecepatan 150 rpm, hal ini bertujuan agar semua nutrisi yang dikandung dalam medium dapat digunakan oleh jamur secara optimal sebagai bahan untuk metabolismenya sehingga senyawa antimikroba dapat dihasilkan dengan optimal. 


\section{Ekstraksi dan Fraksinasi}

Setelah hasil produksi dari kultur cair didapatkan, selanjutnya tahap yang dilakukan adalah ektraksi. Hasil dari kultur cair di ekstraksi dengan menggunakan pelarut aseton. Pengunaan pelarut ini dikarenakan aseton merupakan pelarut polar dan mudah menguap. Aseton yang bersifat polar akan menarik senyawa yang bersifat polar dan non polar (Sarastani et al., 2002). Proses ekstraksi bertujuan untuk memisahkan senyawa aktif yang ada di dalam sampel, sehingga adanya suatu proses pemisahan dua atau lebih komponen yang terkandung dalam sampel oleh suatu pelarut (Suryanto, 2012). Proses ektraksi tidak dilakukan dengan proses ekstraksi panas karena dikhawatirkan adanya golongan senyawa yang tidak tahan panas. Ekstraksi yang dilakukan adalah dengan menggunakan metode maserasi, proses maserasi dilakukan dengan perendaman miselium dan broth jamur dengan menggunakan pelarut aseton. Setelah maserasi selama 6 jam, disaring untuk memisahkan miselium dan filtrat. Hasil dari filtrat kemudian diuapkan menggunakan rotary evaporator. Pengunaan alat ini bertujuan uuntuk menguapkan pelarut dan menghasilkan senyawa ekstraksi yang diinginkan. Hasil dari proses ini adalah ekstrak kental yang kemudian ditambahkan pelarut etil asetat untuk dilakukan fraksinasi.

\section{Uji Aktivitas Antimikroba}

Dalam penelitian ini pengujian aktivitas antimikroba dari jamur yang berasosiasi dengan spons Callyspongia aerizusa. Diuji pada Staphylococcus aureus ATCC 25923 untuk mewakili bakteri golongan Gram positif, Eschrichia coli ATCC 25922 untuk mewakili bakteri golongan Gram negatif dan Candida albicans ATCC 1231 mewakili golongan jamur. Penggunaan mikroba uji ini untuk mengetahui apakah ekstrak kasar dari jamur berasosiasi memiliki aktivitas sebagai antimikroba serta apakah mempunyai spektrum diperluas yaitu dapat membunuh bakteri Gram positif, Gram negatif dan jamur atau mempunyai spektrum sempit yaitu hanya dapat membunuh salah satu dari bakteri Gram positif, Gram negatif atau jamur.

Pada pengujian ini menggunakan metode difusi agar. Metode difusi dilakukan dengan cara disc diffusion (difusi cakram) yaitu kertas yang berisi agen antimikroba untuk menentukan aktivitas antimikroba. Metode difusi cakram dipilih karena memiliki kelebihan dapat digunakan untuk senyawa non polar, cepat, mudah dan sederhana (Valgas et al., 2007). Kertas cakram yang berisi agen antimikroba diletakkan dipermukaan media agar yang sudah diinokulasikan mikroorganisme uji. Agen antimikroba akan berdifusi dari kertas cakram menuju ke media agar dan melakukan penghambatan pertumbuhan mikroorganisme yang diuji. Area jernih mengindikasikan adanya hambatan pertumbuhan mikroorganisme oleh agen antimikroba pada permukaan media agar. Pada pengujian ini, hasil yang diperoleh yaitu terbentuknya zona hambat disekeliling cakram yang ditandai dengan adanya area bening. Hal ini menunjukkan bahwa adanya kepekaan mikroba terhadap ekstrak jamur yang diisolasi dari spons Callyspongia aerizusa. Dalam 
pengujian ini digunakan kontrol positif dan negatif. Penggunaan kontrol positif berfungsi sebagai kontrol dari zat uji, dengan membandingkan diameter daerah hambat yang terbentuk (Dwijendra, 2014). Sedangkan tujuan penggunaan kontrol negatif agar dapat mengetahui apakah ada atau tidak pengaruh pelarut terhadap pertumbuhan mikroba uji, sehingga dapat dipastikan bahwa aktivitas yang ditunjukkan oleh ekstrak ialah senyawa yang digunakan. Dalam penelitian ini, kontrol negatif menggunakan pelarut metanol.

Tabel 1 Hasil Pengukuran rata-rata zona hambat antimikroba ekstrak jamur yang berasosiasi dengan spons Callyspongia aerizusa terhadap bakteri S. aureus ATCC 25923, E. coli ATCC 25922 dan jamur $C$. albicans ATCC 1231

\begin{tabular}{|l|c|c|c|}
\multirow{2}{*}{ Perlakuan } & \multicolumn{3}{|c|}{ Rata - Rata Diameter Total(mm) } \\
\cline { 2 - 4 } & $\begin{array}{c}\text { Staphylococcls } \\
\text { aureus }\end{array}$ & $\begin{array}{c}\text { Escherichia } \\
\text { coli }\end{array}$ & $\begin{array}{l}\text { Candida } \\
\text { albicans }\end{array}$ \\
\hline $\begin{array}{l}\text { Ekstrak } \\
\text { EtilAsetat }\end{array}$ & 0 & 6,63 & 6,78 \\
\hline $\begin{array}{l}\text { Kontrol } \\
\text { Positif }\end{array}$ & 26,2 & 22,2 & 23,9 \\
\hline $\begin{array}{l}\text { Kontrol } \\
\text { Negatif }\end{array}$ & 0 & 0 & 0 \\
\hline
\end{tabular}

Hasil yang didapat pada penelitian ini yaitu adanya zona bening terbentuk disekitaran kertas cakram. Pengukuran zona hambat dilakukan dengan cara mengukur jarak dari tepi ke batas lingkaran zona hambat menggunakan jangka sorong $(0,01 \mathrm{~mm})$ pada beberapa isi kertas cakram dan dirata-ratakan. Menurut Susanto (2012), Penilaian zona hambat di golongkan berdasarkan kategori diameter zona hambat di mana diameter $\leq 5 \mathrm{~mm}$ berarti daya hambatnya lemah, jika 6-10 $\mathrm{mm}$ berarti kekuatan daya hambatnya sedang,jika 11-20 mm berarti daya hambatnya kuat, dan jika di atas $21 \mathrm{~mm}$ berarti daya hambatnya sangat kuat.

Dari pengukuran rata-rata diameter zona hambat (Tabel 1 ), daya antimikroba dari sampel spons Callyspongia aerizusa pada bakteri $S$. aureus ATCC 25923 hasil yang diperoleh yaitu tidak terbentuknya zona hambat disekeliling cakram yang ditandai dengan tidak terbentuk area bening. Hal ini menunjukkan tidak ada kepekaan mikroba terhadap sampel spons Callyspongia aerizusa. Pada bakteri E. coli ATCC 25922 hasil yang diperoleh sebesar 6,63 $\mathrm{mm}$ hal ini termasuk dalam kekuatan sedang. Dan untuk jamur $C$. albicans ATCC 1231 hasil yang diperoleh $6,78 \mathrm{~mm}$ hal ini termasuk dalam kekuatan sedang. Kontrol positifnya digunakan antibiotik kloramfenikol,Kloramfenikol digunakan untuk melawan infeksi yang disebabkan oleh beberapa jenis bakteri Gram positif dan bakteri Gram negatif. Kloramfenikol mempunyai khasiat bakterisid (Sumardjo, 2009). Penggunaan kontrol positif berfungsi sebagai kontrol zat uji, dengan membandingkan diameter hambat yang terbentuk. Dari hasil pengujian kontrol positif menghasilkan adanya zona hambat dari bakteri S. aureus ATCC 2592 26,2 $\mathrm{mm}$ termasuk sangat kuat, pada bakteri , E. coli ATCC 25922 22,2 mm termasuk sangat kuat, pada jamur C. albicans ATCC 1231 23,9 mm termasuk sangat kuat. Penggunaan metanol sebagai kontrol negatif diperkuat dengan penelitian oleh Ginting (2010), yang menyatakan bahwa kontrol metanol pada 
uji antibakteri tidak menunjukan adanya aktivitas sehingga dapat dipastikan bahwa metanol tidak berpengaruh terhadap aktivitas yang terbentuk. Dari hasil pengujian diperoleh kontrol negatif tidak terbentuk zona hambat. Hal ini membuktikan bahwa kontrol yang digunakan tidak berpengaruh pada uji antimikroba, sehingga daya hambat yang terbentuk tidak dipengaruhi oleh pelarut methanol melainkan karena aktivitas senyawa yang ada pada spons Callyspongia aerizusa.

\section{KESIMPULAN}

Berdasarkan hasil penelitian yang telah dilakukan dapat disimpulkan bahwa, jamur laut yang berasosiasi dengan spons Callyspongia aerizusa yang diperoleh dari Desa Tumbak, Kecamatan Pusomaen, Minahasa Tenggara memiliki aktivitas menghambat pertumbuhan bakteri Escherichia coli dan jamur Candida albicans yang memiliki kategori kekuatan daya hambat sedang.

\section{SARAN}

Berdasarkan penelitian yang telah dilakukan penulis memberikan saran bahwa perlu dilakukan penelitian lebih lanjut mengenai uji aktivitas antimikroba terhadap jamur yang berasosiasi dengan spons, dengan beragam metode uji dan tempat pengambilan sampel yang berbeda.

\section{DAFTAR PUSTAKA}

Bugni, T. S and Ireland, C. M. 2004. Marine-derived fungi: A Chemically and Biologically Diverse Group of Microorganisms. Natural Production. 21 : 143-63.

Dwijendra, I. M. 2014. Aktivitas Antibakteri dan Karakterisasi Senyawa Fraksi Spons Lamellodysidea herbacea yang Diperoleh dari Teluk Manado [skripsi]. Program Studi Farmasi FMIPA Universitas Sam Ratulangi, Manado.

Dwyana, Z dan Johanes E. 2012. Uji Efektivitas Ekstrak Kasar Alga Merah Eucheuma Cottoni Sebagai Antibakteri Terhadap Bakteri Patogen. [Skripsi]. Program Studi Biologi Universitas Hasanudin, Makassar.

Ginting, E. L., Warouw, V., Suleman, R. W. 2010. Aktivitas Antibakteri Dari Ekstrak Kasar Bakteri Yang Berasosiasi Dengan Sponge Acanthostrongylophora $s p$. [skripsi]. Fakultas Perikanan dan Ilmu Kelautan Universitas Sam Ratulangi, Manado. 